\title{
FAKTOR-FAKTOR YANG MEMPENGARUHI TAX $A$ VOIDANCE DENGAN KEPEMILIKAN INSTITUSIONAL SEBAGAI VARIABEL MODERASI
}

\author{
Alya Zulfa Cahyani ${ }^{1}$, Syahril Djaddang ${ }^{2}$, Mombang Sihite ${ }^{3 *}$ \\ 1,2,3 Program Studi Magister Akuntansi, Universitas Pancasila \\ *e-mail: zulfacalya@gmail.com
}

\begin{abstract}
DiPublikasi: 01/07/2021
https://doi.org/10.22225/kr.13.1.2021.122-135

Abstract

This study aims to examine the effect of Thin Capitalization, Capital Intensity, and Fiscal Loss Compensation on Tax Avoidance and to examine the effect of Institutional Ownership in moderating Thin Capitalization on Tax Avoidance in mining sector companies listed on the Indonesia Stock Exchange for the 2017-2019 period. This study uses a sample of 20 mining sector companies listed on the Indonesian Stock Exchange for the 2017-2019 period with the sampling technique using purposive sampling method and research data using secondary data. The data analysis used moderated regression analysis with SPSS 25.0 software. The results of this study indicate that Thin Capitalization has no effect on Tax Avoidance, while Capital Intensity and Fiscal Loss Compensation have an effect on Tax Avoidance and Institutional Ownership cannot moderate Thin Capitalization on Tax Avoidance.
\end{abstract}

Keywords: Capital Intensity, Institusional Ownership, Tax Avoidance, Fiscal Loss Compensation, Thin Capitalization

\begin{abstract}
Abstrak
Penelitian ini bertujuan untuk menguji pengaruh Thin Capitalization, Intensitas Modal, dan Kompensasi Rugi Fiskal terhadap Penghindaran Pajak dan untuk menguji Kepemilikan Institusional dalam memoderasi pengaruh Thin Capitalization terhadap Penghindaran Pajak pada perusahaan sektor pertambangan yang terdaftar di Bursa Efek Indonesia tahun 2017- Periode 2019. Penelitian ini menggunakan sampel sebanyak 20 perusahaan sektor pertambangan yang terdaftar di Bursa Efek Indonesia periode 2017-2019 dengan teknik pengambilan sampel menggunakan metode purposive sampling dan data penelitian menggunakan data sekunder. Analisis data menggunakan analisis regresi moderasi dengan software SPSS 25.0. Hasil penelitian ini menunjukkan bahwa Thin Capitalization tidak berpengaruh terhadap Penghindaran Pajak, sedangkan Intensitas Modal dan Kompensasi Rugi Fiskal berpengaruh terhadap Penghindaran Pajak dan Kepemilikan Institusional tidak dapat memoderasi Thin Capitalization terhadap Penghindaran Pajak.
\end{abstract}

Kata Kunci : Intensitas Modal, Kepemilikan Institusional, Penghindaran Pajak, Kompensasi Rugi Fiskal, Thin Capitalization

\section{PENDAHULUAN}

Pajak merupakan kontribusi wajib kepada negara yang terutang oleh orang pribadi atau badan usaha dan tidak mendapatkan timbal balik secara langsung yang pemungutannya dilakukan oleh pemerintah berdasarkan undang-undang yang bersifat memaksa (Darmawan \& Sukartha, 2014). Dari sisi perusahaan, Pajak dianggap sebagai beban dimana akan menambah pengeluaran dan yakni mengecilkan laba suatu perusahaan. Maka dari itu, banyak perusahaan yang berupaya untuk memperkecil pajak yang akan dibayarkan atau yang dikenal dengan Tax Avoidance. Tax avoidance (penghindaran pajak) merupakan usaha yang dilakukan untuk mengecilkan pajak terutang yang masih bersifat legal, namun menimbulkan resiko bagi perusahaan, baik dikenakan denda oleh pemerintah, serta reputasi yang buruk dimata masyarakat (Kalbuana et al., 2017). Menurut (Widodo et al., 2020) pengukuran penghindaran pajak dihitung menggunakan proksi Effective tax rate (ETR) .ETR digunakan untuk mencerminkan penghindaran pajak dan merupakan rasio yang dihitung dengan membagi beban pajak dengan laba sebelum pajak penghasilan. Asumsinya apabila suatu perusahaan diketahui melakukan 
penghindaran pajak, maka menyebabkan nilai ETR yang rendah dan variabel independen yang dimiliki menunjukkan nilai koefisien negatif terhadap ETR, dapat diartikan memiliki hubungan positif dengan penghindaran pajak dan sebaliknya.
Sektor pertambangan merupakan salah satu dari lima sektor penyumbang pajak terbesar bagi negara. Namun hal ini berbanding terbalik dengan penerimaan pajak yang diterima negara.

\section{Fenomena mengenai Tax Avoidance dalam perusahaan sektor Pertambangan Tahun 2017- 2019}

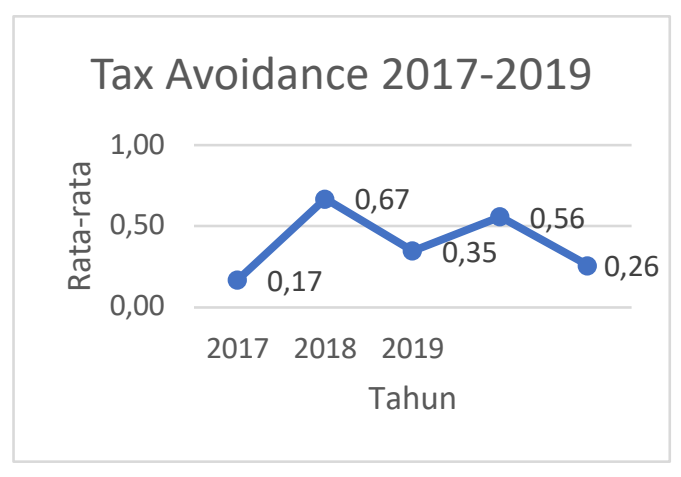

Sumber: Hasil Pengolahan Data, 2020

Berdasarkan grafik diatas, Pada tahun 2017 dapat dilihat perusahaan yang melakukan penghindaran pajak sebesar 0,35. Di tahun 2018 mengalami kenaikan yang tidak terlalu signifikan sebesa 0,56. Lalu ditahun 2019 mengalami penurunan yang cukup signifikan sebesar 0,26. Hal ini dikarenakan ada beberapa perusahaan yang beban pajak dan laba sebelum pajak mengalami kerugian (negatif), sehingga nilai ETR menjadi kecil yang menyebabkan perusahaan melakukan penghindaran pajak. Maka dapat disimpulkan, bahwa Wajib Pajak (perusahaan sector pertambangan) masih ada yang melakukan praktik penghindaran pajak. Hal ini terlihat dari grafik di atas yang naik turun (Fluktuatif).

(Taylor \& Richardson, 2013) menjelaskan bahwa faktor utama pendorong praktik penghindaran pajak adalah thin capitalization. Thin capitalization adalah suatu praktik dengan membuat struktur utang jauh lebih besar dibandingkan modal perusahaan. Perusahaan dapat menaikkan jumlah pinjaman, dimana hal ini akan menyebabkan beban bunga meningkat dan menjadikan penghasilan kena pajak semakin kecil, hal ini akan berdampak pada pendapatan yang diterima negara. Faktor lain yang dapat mendorong perusahaan melakukan penghindaran pajak adalah capital intensity atau intensitas modal. Intensitas modal adalah kegiatan investasi yang dilakukan perusahaan yang dihubungkan dengan investasi berbentuk aset tetap (modal). Kepemilikan aset tetap yang tinggi akan menghasilkan beban penyusutan yang tinggi juga, sehingga laba akan turun dan beban pajak perusahaan akan turun juga..

Selain itu berdasarkan (UndangUndang No. 36 Tahun 2008 Tentang Pajak Penghasilan, 2008) pasal 6 ayat 2 tentang pajak penghasilan bahwa, perusahaan yang telah merugi selama satu periode akuntansi mendapatkan keringanan yakni untuk tidak membayar pajak, dimana kerugian tersebut akan dikompensasikan selama lima tahun ke depan yang mengakibatkan laba perusahaan akan menurun karena digunakan untuk mengurangi jumlah kerugian tersebut sehingga perusahaan akan terhindar dari beban pajak. Faktor lain yang diduga mempengaruhi Tax avoidance yaitu Kepemilikan institusional. Semakin besar kepemilikan institusional maka semakin kecil kebijakan pajak agresif (Zemzem \& Ftouhi, 2013)

Pada penelitian yang dilakukan oleh (Fadila, 2017) menyatakan bahwa Kompensasi 
Rugi Fiskal dan Kepemilikan Institusional berpengaruh terhadap Penghindaran Pajak. Sedangkan menurut (Waluyo et al., 2015) menyatakan bahwa Kompensasi Rugi fiskal dan Kepemilikan Institusional tidak berpengaruh terhadap penghindaran pajak. (Charisma \& Dwimulyani, 2019)menyatakan Kepemilikan Institusional berpengaruh negative terhadap Penghindaran Pajak. Adapun penelitian yang dilakukan (Ismi \& Linda, 2016) menyatakan bahwa Thin capitalization berpengaruh positif dan tidak signifikan terhadap Penghindaran Pajak. Sedangkan (Widodo et al., 2020) menyatakan bahwa Thin capitalization berpengaruh signifikan terhadap Penghindaran Pajak. Penelitian yang dilakukan oleh (Suprianto \& Aqida, 2020) menyatakan bahwa Intensitas Modal (Capital Intensity) berpengaruh positif terhadap Penghindaran Pajak. Sedangkan (Muzakki \& Darsono, 2015) menyatakan bahwa Intensitas Modal

\section{TINJAUAN PUSTAKA}

\section{Teori Agensi (Agency Theory)}

(Jensen \& Meckling, 1976) menyatakan bahwa hubungan keagenan sebagai kontrak antara satu atau beberapa orang (pemberi kerja atau principal) yang mempekerjakan orang lain (agent) untuk melakukan sejumlah jasa dan memberikan wewenang dalam pengambilan keputusan. . Terdapat beberapa cara untuk mengontrol tindakan agent terkait dengan kegiatan manajemen pajak yang dilakukan, yaitu dengan mengevaluasi hasil laporan keuangan perusahaan dengan menggunakan rasio keuangan yang dibandingkan dengan tindakan agresivitas pajak yang mungkin dilakukan oleh agent. Rasio yang digunakan yaitu membandingkan ETR perusahaan yang didapat dari beban pajak dibandingkan dengan laba sebelum pajak.

\section{Akuntansi Perpajakkan}

Akuntansi pajak menurut (Agoes, 2013) adalah menetapkan besarnya pajak terutang berdasarkan laporan keuangan suatu perusahaan. Fungsi akuntansi pajak yaitu untuk mengolah data kuantitatif yang akan digunakan untuk Menyusun laporan keuangan yang memuat perhitungan perpajakan. berpengaruh negative terhadap Penghindaran Pajak, Adapun tujuan dari penelitian ini adalah untuk menganalisis dan menginvestigasi pengaruh Thin Capitalization, Capital Intensity, dan Kompensasi Rugi Fiskal terhadap Tax Avoidance serta untuk menganalisis dan menginvestigasi Kepemilikan Institusional dalam memoderasi pengaruh

Thin Capitalization terhadap Tax Avoidance. Manfaat dari penelitian ini adalah untuk memberikan tambahan informasi, wawasan, dan pengetahuan khususnya dalam bidang perpajakkan yang berkaitan dengan Tax Avoidance atau Penghindaran Pajak di Indonesia serta untuk memberikan gambaran mengenai keadaan perusahaan yang mana dapat dijadikan sebagai bahan pertimbangan dalam menentukan keputusan untuk berinvestasi. Khususnya untuk perusahaan sektor pertambangan yang terdaftar di Bursa Efek Indonesia

(BEI).

\section{Pajak}

Menurut (Undang-Undang Nomor 28 Tahun 2007 Tentang Perubahan Ketiga Atas Undang-Undang Nomor 6 Tahun 1983 Tentang Ketentuan Umum Dan Tata Cara Perpajakan, 2007)"Pajak adalah kontribusi wajib kepada negara yang terutang oleh orang pribadi atau badan yang bersifat memaksa berdasarkan Undang-Undang, dengan tidak mendapatkan imbalan secara langsung dan digunakan untuk keperluan negara bagi sebesar-besarnya kemakmuran rakyat.

\section{Tax Avoidance}

Penghindaran pajak merupakan usaha meminimkan beban pajak dengan cara penggunaan alternatif-alternatif yang riil dan dapat diterima oleh fiscus (Mulyana et al., 2020). Jadi, penghindaran pajak merupakan tindakan yang legal secara hukum, karena tidak melanggar peraturan undang-undang perpajakan. Namun penghindaran pajak ini merupakan suatu hal yang unik, karena di satu sisi dilegalkan secara hukum tapi disisi lain tindakan penghindaran pajak ini tidak sangat dihindarkan pemerintah karena akan berdampak terhadap penerimaan negara.

Thin Capitalization 
Thin Capitalization adalah pembentukan struktur modal perusahaan dengan kombinasi kepemilikan hutang yang banyak dan modal yang kecil (Taylor \& Richardson, 2013). (Peraturan Menteri Keuangan Nomor. 169/PMK.010/2015, 2015) menyebutkan Penentuan Besarnya Perbandingan antara Hutang dan Modal Perusahaan untuk Keperluan Penghitungan Pajak Penghasilan ditetapkan paling tinggi sebesar empat dibanding satu $(4: 1)$

\section{Capital Intensity}

Capital Intensity merupakan salah satu keputusan keuangan yang ditetapkan oleh pihak manajemen perusahaan untuk meningkatkan profitabilitas perusahaan, (Mulyani et al., 2012) Rasio intensitas modal ini penting bagi kreditor dan pemilik perusahaan, tetapi akan lebih penting lagi bagi manajemen perusahaan, karena rasio intensitas modal dapat menunjukkan tingkat efisiensi perusahaan dalam menggunakan aktivanya untuk menghasilkan penjualan.

\section{Kompensasi Rugi Fiskal}

Kompensasi Rugi Fiskal adalah kerugian fiskal perusahaan yang dapat dikompensasikan yang hanya diperkenankan selama lima tahun kedepan secara berturut-turut. Namun apabila telah melewati tahun kelima dan masih terdapat kerugian, maka kerugian tersebut tidak dapat dikompensasikan kembali ditahun berikutnya dan perusahaan akan melakukan kewajiban perpajakannya secara normal (Mulyana et al., 2020)

\section{Kepemilikan Institusional}

Kepemilikan institusional merupakan kepemilikan saham yang dimiliki oleh pemerintah, perusahaan asuransi, investor badan luar negeri atau bank (Dewi \& Jati, 2014). Keberadaan kepemilikan oleh investor institusional mampu mengawasi kinerja manajer (Jensen \& Meckling, 1976).

\section{Kerangka Pemikiran}

Gambar 2.

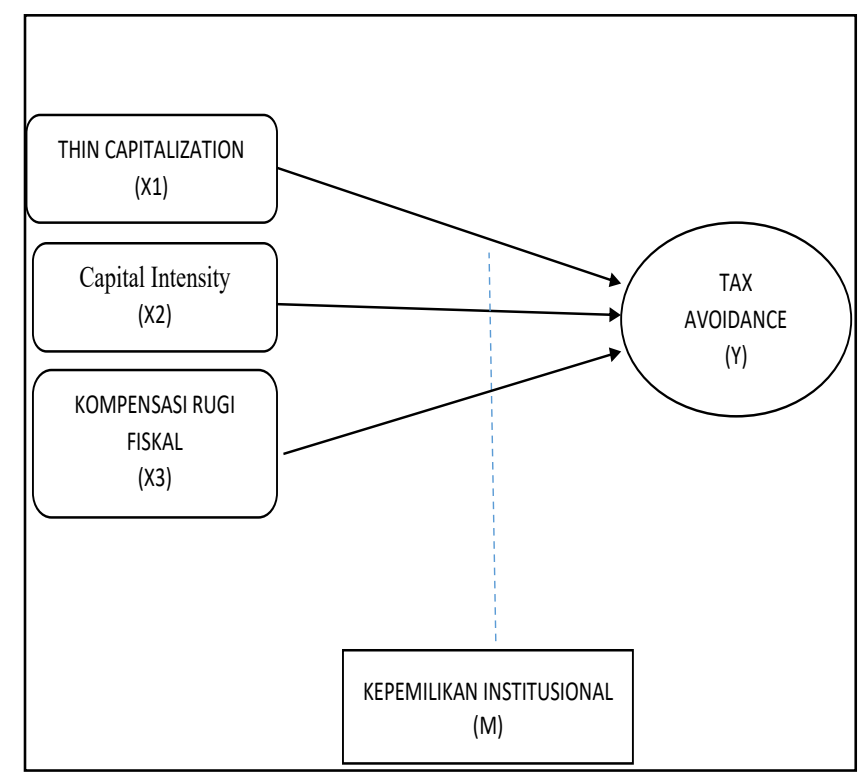

Hipotesis

Pengaruh Thin Capitalization terhadap Tax Avoidance capitalization dengan memanfaatkan perbedaan peraturan pajak. Perbedaan tersebut terkait dengan pembayaran bunga yang dapat dikategorikan sebagai Perusahaan melakukan praktik thin pengurang pajak, sedangkan pengeluaran atas 
deviden yang dibayarkan kepada pemilik dana tidak tergolong beban pengurang pajak (Houston \& Eugene, 2006). Semakin tinggi hutang, maka semakin tinggi bunga yang harus dibayar oleh perusahaan kepada kreditur, sehingga semakin rendah laba kena pajak. Strategi ini kemudian digunakan oleh perusahaan untuk melakukan penghindaran pajak melalui meningkatan rasio hutang terhadap modal (DER). Penelitian yang dilakukan oleh (Widodo et al., 2020) (Khomsatun \& Martani, 2015) dan (Sueb, 2020) menyebutkan bahwa Thin Capitalization berpengaruh positif signifikan terhadap praktik penghindaran pajak.

$\mathrm{H} 1$ : Thin capitalization berpengaruh terhadap Tax Avoidance

\section{Pengaruh Capital Intensity terhadap Tax Avoidance}

Intensitas Modal mencerminkan besaran modal yang dibutuhkan suatu perusahaan untuk memperoleh laba, dimana sumber dana salah satunya diperoleh dari penurunan aktiva tetap ataupun kenaikan jumlah aktiva tetap. Biaya depresiasi aset tetap ini menjadi penambah beban perusahaan dan menurunkan laba. hal ini terjadi karena penyusutan aset tetap perusahaan dari tahun ke tahun yang secara langsung dapat menurunkan laba yang menjadi dasar perhitungan pajak. Sehingga semakin tinggi capital intensity maka semakin tinggi juga penghindaran pajak yang dilakukan. Penelitian yang dilakukan oleh (Anggraini et al., 2020), (Muzakki \& Darsono, 2015), (Suprianto \& Aqida, 2020) menyebutkan bahwa Capital intensity berpengaruh positif terhadap Tax avoidance.

$\mathrm{H} 2$ : Capital Intensity berpengaruh terhadap Tax Avoidance

Pengaruh Kompensasi Rugi Fiskal terhadap Tax Avoidance

Secara logika, suatu perusahaan yang telah merugi dalam satu periode akuntansi diberikan keringanan untuk membayar pajaknya, dimana

\section{METODE PENELITIAN}

\section{Desain Penelitian}

Penelitian ini termasuk dalam penelitian asosiatif dengan desain penelitian kausal Dimana variabel independen dalam penelitian ini adalah Informasi arus kas, Laba akuntansi, Ukuran perusahaan, dan Leverage. Variabel dependen dalam penelitian ini adalah Return saham. Kemudian dalam penelitian ini ditambahkan variabel moderasi vaitu kerugian tersebut dapat dikompensasikan selama lima tahun ke depan dan laba perusahaan akan digunakan untuk mengurangi jumlah kompensasi kerugian tersebut. Hal ini mengakibatkan perusahaan akan terhindar dari beban pajak selama lima tahun, karena laba kena pajak akan digunakan untuk mengurangi jumlah kompensasi kerugian perusahaan. Kompensasi Rugi Fiskal dapat dimanfaatkan sebagai penghindaran pajak karena perusahaan yang mendapatkan kompensasi kerugian akan terbebas dari beban pajak yang tinggi (Pajriyansyah \& Firmansyah, 2017) Penelitian yang dilakukan oleh (Pajriyansyah \& Firmansyah, 2017), (Putri, 2020) dan (Ginting, 2016) yang menyebutkan bahwa Kompensasi Rugi Fiskal berpengaruh positif terhadap Tax avoidance.

H3 : Kompensasi rugi fiskal berpengaruh terhadap Tax Avoidance

\section{Pengaruh Kepemilikan Institusional dalam memoderasi Pengaruh Thin Capitalization terhadap Tax Avoidance}

Teori agensi menyatakan bahwa agen akan berusaha mengelola beban pajaknya agar tidak mengurangi kompensasi kinerja agen sebagai akibat dari tergerusnya laba perusahaan oleh beban pajak. Dengan demikian agen akan cenderung melakukan aktivitas penghindaran pajak agresif. Dengan adanya Kepemilikan Institusional sebagai salah satu elemen corporate governance, maka diharapkan perusahaan akan menyeimbangkan modal dari utang dan investasi modal dari pemegang saham dalam struktur modalnya. Penelitian yang dilakukan oleh (Jumailah \& Mulyani, 2020) menyebutkan bahwa kepemilikan institusional dapat memperlemah pengaruh Thin Capitalization terhadap Tax Avoidance.

H4 : Kepemilikan Intistusional dapat memoderasi pengaruh Thin Capitalization terhadap Tax Avoidance

kepemilikan institusional yang dapat memperkuat atau memperlemah variabel independen terhadap variabel dependen.

\section{Populasi dan Sampel}

Populasi dalam penelitian ini adalah perusahaan sektor pertambangan yang terdaftar di Bursa Efek Indonesia periode 2017-2019 yaitu sebanyak 49. Kemudian, sampel dalam penelitian ini 
berjumlah 20 perusahaan sector pertambangan yang terdaftar di Bursa Efek Indonesia periode 2017-2019 dengan Teknik pengambilan sampel yang digunakan adalah purposive sampling dengan kriteria sebagai berikut:

1. Perusahaan sector Pertambangan yang terdaftar di Bursa Efek Indonesia dari tahun 2017-2019

2. Perusahaan sector Pertambangan dengan tahun IPO dibawah tahun 2017

3. Perusahaan sector Pertambangan yang selama periode penelitian berturut-turut mempublikasikan laporan keuangannya di Bursa Efek Indonesia (BEI)

\section{Teknik Pengumpulan Data}

Teknik pengumpulan dalam penelitian ini menggunakan data Arsip yang diperoleh dari laporan keuangan perusahaan sektor pertambangan yang terdaftar dalam Bursa Efek Indonesia melalui situs www.idx.id periode 2017-2019.

\section{Pengukuran Variabel \\ Tax Avoidance}

Variabel Tax Avoidance diukur menggunakan proksi Effective tax rate (ETR) (Widodo et al., 2020)

$$
\mathrm{ETR}=\frac{\text { Beban Pajak }}{\text { Laba sebelum pajak }}
$$

\section{Thin Capitalization}

Berdasarkan

(Peraturan Menteri

Keuangan Nomor. 169/PMK.010/2015, 2015) variabel Thin capitalization diukur menggunakan: Debt to Equity Ratio (DER) = Total Hutang

Capital Intensity Total Ekuitas

Variabel Capital Intensity diukur menggunakan (Mulyani et al., 2012) :
Capital Intensity $=$ Total aset tetap

Total asset

\section{Kompensasi Rugi Fiskal}

Variabel Kompensasi Rugi Fiskal diukur dengan dengan Variabel dummy yaitu memberikan nilai 1 jika terdapat kompensasi rugi fiskal pada awal tahun $t$ (Pajriyansyah \& Firmansyah, 2017).

\section{Kepemilikan Institusional}

(Budiadnyani, 2020) mengukur variabel Kepemilikan Institusional dengan formula sebagai berikut.

$$
\begin{gathered}
\mathrm{KI}=\sum \mathrm{SI} \\
\text { Keterangan: } \\
\mathrm{KI}=\text { Kepemilikan institusional } \\
\mathrm{SI}=\text { Saham yang dimiliki oleh institusi } \\
\mathrm{ST}=\text { Jumlah saham yang diterbitkan }
\end{gathered}
$$

\section{Metode Analisis Data}

Peneletian ini menggunakan metode Moderated regression analysis (MRA) yaitu pendekatan analitik yang mempertahankan itegritas sampel dan memberikan dasar untuk mengontrol pengaruh variabel moderator (Ghozali, 2018) dengan software SPSS 25.0. Pengujian akan dilakukan dengan model regresi moderasi sebagai berikut:

$$
\mathrm{Y}=\mathrm{a}+\mathrm{b}_{1} \mathrm{X}_{1}+\mathrm{b}_{2} \mathrm{X}_{2}+\mathrm{b}_{3} \mathrm{X}_{3}+\mathrm{b}_{4} \mathrm{X}_{1} \cdot \mathrm{Z}+\mathrm{e}
$$

\section{Keterangan:}

$$
\begin{array}{ll}
\mathrm{Y} & =\text { Tax Avoidance } \\
\mathrm{a} & =\text { Konstanta }
\end{array}
$$

$\mathrm{b}(1,2,3,4)=$ Koefisien Regresi

$$
\begin{aligned}
& \mathrm{X}_{1} \quad=\text { Thin Capitalization } \\
& \mathrm{X}_{2} \quad=\text { Capital Intensity } \\
& \mathrm{X}_{3} \quad=\text { Kompensasi Rugi Fiskal } \\
& \mathrm{Z}=\text { Kepemilikan Institusional } \\
& \text { e } \quad=\text { Standar error }
\end{aligned}
$$

\section{HASIL DAN PEMBAHASAN Hasil Analisis Deskriptif}




\section{Tabel 1}

\section{Descriptive Statistics}

\begin{tabular}{lc|r|r|r|r} 
& $\mathrm{N}$ & $\begin{array}{r}\text { Mini } \\
\text { mum }\end{array}$ & $\begin{array}{c}\text { Maxi } \\
\text { mum }\end{array}$ & Mean & $\begin{array}{c}\text { Std. } \\
\text { Deviation }\end{array}$ \\
\hline $\begin{array}{l}\text { Thin } \\
\text { Capitalization }\end{array}$ & 60 & .00 & 2.87 & .8487 & .57473 \\
\hline $\begin{array}{l}\text { Capital } \\
\text { Intensity }\end{array}$ & 60 & .00 & .68 & .2567 & .17232 \\
\hline $\begin{array}{l}\text { Kepemilikan } \\
\text { Institusional }\end{array}$ & 60 & .00 & .97 & .6633 & .26283 \\
\hline $\begin{array}{l}\text { Tax } \\
\text { Avoidance }\end{array}$ & 60 & .00 & .47 & .2397 & .12286 \\
\hline $\begin{array}{l}\text { TC_KI } \\
\text { Valid N } \\
\text { (listwise) }\end{array}$ & 60 & .00 & 1.88 & .5547 & .44423 \\
\hline
\end{tabular}

Sumber: Output SPSS 25 Tahun 2020

Tabel 2

Statistik Deskriptif Frekuensi (Dummy)

\begin{tabular}{|ccr|r|r|r} 
& & $\begin{array}{c}\text { Fre } \\
\text { que } \\
\text { ncy }\end{array}$ & $\begin{array}{c}\text { Perce } \\
\text { nt }\end{array}$ & $\begin{array}{c}\text { Valid } \\
\text { Percent }\end{array}$ & $\begin{array}{c}\text { Cumulative } \\
\text { Percent }\end{array}$ \\
\hline Valid & .00 & 45 & 75.0 & 75.0 & 75.0 \\
\cline { 2 - 7 } & 1.00 & 15 & 25.0 & 25.0 & 100.0 \\
\cline { 2 - 7 } & Total & 60 & 100.0 & 100.0 & \\
\hline
\end{tabular}

Sumber: Output SPSS 25 Tahun 2020

Variabel Independen yang pertama dalam penelitian ini adalah Kompensasi Rugi Fiskal. penelitian ini adalah Thin Capitalization. Pengukuran variabel Kompensasi Rugi Fiskal ini Berdasarkan hasil uji statistik deskriptif pada tabel 1, menggunakan variabel dummy. Berdasarkan hasil uji dapat diketahui nilai minimum Thin Capitalization statistik deskriptif frekuensi tabel 2 diatas sebesar 0,00 dan niai maksimum sebesar 2,87. Nilai menunjukkan nilai minimum Kompensasi Rugi rata-rata (mean) Thin Capitalization sebesar 0,8487 Fiskal sebesar 0, dan nilai maksimum sebesar 1. dengan standar deviasi sebesar 0,57473. Hal ini Kompensasi Rugi Fiskal dari total 60 sampel berarti bahwa nilai rata-rata (mean) lebih besar dari diperoleh 45 sampel atau $75 \%$ dengan nilai dummy nilai standar deviasi, sehingga mengindikasikan 0,00 sedangkan 15 sampel atau $25 \%$ dengan nilai penyebaran data yang baik. Variabel Independen dummy 1,00. Variabel moderasi dalam penelitian ini yang kedua dalam penelitian ini adalah Capital adalah Kepemilikan Institusional. Berdasarkan hasil Intensity. Dari hasil uji statistik deskriptif diatas, uji statistik deskriptif pada tabel 1, dapat diketahui dapat diketahui nilai minimum Capital Intensity nilai minimum Kepemilikan Institusional sebesar sebesar 0,00, sedangkan nilai maksimum Capital 0,00, dan nilai maksimum sebesar 0,97. Nilai rataIntensity sebesar 0,68. Nilai rata-rata (mean) Capital rata (mean) Kepemilikan Institusional sebesar 0,6633 Intensity sebesar 0,2567 dengan standar deviasi dengan standar deviasi sebesar 0,26283. Hal ini sebesar 0,17232. Hal ini berarti bahwa nilai rata-rata berarti bahwa nilai rata-rata (mean) lebih besar dari (mean) lebih besar dari nilai standar deviasi, nilai standar deviasi, sehingga mengindikasikan sehingga mengindikasikan penyebaran data yang penyebaran data yang baik. baik.

Variabel Dependen dalam penelitian ini Variabel Independen vang ketiga dalam adalah Tax Avoidance. Berdasarkan hasil uii statistik 
deskriptif pada tabel 1, dapat diketahui nilai minimum Tax Avoidance sebesar 0,00, sedangkan nilai maksimum Tax Avoidance sebesar 0,47. Nilai rata-rata (mean) Tax Avoidance sebesar 0,2397 dengan standar deviasi sebesar 0,12286. Hal ini berarti bahwa nilai rata-rata (mean) lebih besar dari nilai standar deviasi, sehingga mengindikasikan penyebaran data yang baik. Berdasarkan hasil uji statistik deskriptif pada tabel 1, dapat diketahui variabel Thin Capitalization yang telah dimoderasi dengan Kepemilikan Institusional memiliki nilai minimum sebesar 0,00 sedangkan niai maksimum sebesar 2,87 . Nilai rata-rata (mean) Thin Capitalization yang telah dimoderasi dengan Kepemilikan Institusional Kepemilikan Institusional sebesar 0,5547 dengan standar deviasi sebesar 0,44423 . Hal ini berarti bahwa nilai rata-rata (mean) lebih besar dari nilai standar deviasi, sehingga mengindikasikan penyebaran data yang baik.

Hasil Uji Asumsi Klasik Hasil Uji Normalitas

Uji normalitas dalam penelitian ini menggunakan uji Kolmogorov-Smirnov.

\section{Tabel 3}

Uji Normalitas

\begin{tabular}{ll} 
& $\begin{array}{c}\text { Unstandar } \\
\text { dized } \\
\text { Residual }\end{array}$ \\
\hline $\mathrm{N}$ & 60 \\
\hline $\begin{array}{l}\text { Asymp. Sig. (2- } \\
\text { tailed) }\end{array}$ & $.200^{\mathrm{c}, \mathrm{d}}$ \\
\hline
\end{tabular}

a. Test distribution is Normal

Sumber: Output SPSS 25 Tahun 2020

Hasil uji Kolmogorov-Smirnov pada maka dapat disimpulkan bahwa data berdistribusi penelitian ini menunjukkan besarnya K-S untuk nilai normal. Asymp.sig (2-Tailed) adalah 0,20 berada diatas 0,05,

\section{Hasil Uji Multikolinearitas}

Tabel 4

Uji Multikolinearitas Coefficients $^{\mathrm{a}}$

\begin{tabular}{|c|c|c|c|}
\hline Model & & $\begin{array}{c}\text { Toleran } \\
\text { ce }\end{array}$ & VIF \\
\hline \multirow{5}{*}{1} & (Constant) & & \\
\hline & $\begin{array}{l}\text { Thin } \\
\text { Capitalization }\end{array}$ & .233 & 4.290 \\
\hline & $\begin{array}{l}\text { Capital } \\
\text { Intensity }\end{array}$ & .918 & 1.090 \\
\hline & $\begin{array}{l}\text { Kompensasi } \\
\text { Rugi Fiskal }\end{array}$ & .963 & 1.039 \\
\hline & TC KI & .235 & 4.249 \\
\hline
\end{tabular}

Sumber: Output SPSS 25 Tahun 2020 
Berdasarkan tabel 4 diatas dapat dilihat bahwa Seluruh variabel independen memiliki nilai tolerance $>0,10$ dan nilai VIF $<10$. Hal ini dapat disimpulkan bahwa model regresi dalam penelitian ini tidak terjadi multikolinearitas dan model regresi layak digunakan.

\section{Hasil Uji Heteroskedastisitas}

Uji hetereoskedastisitas dalam penelitian ini dilakukan dengan melihat Grafik Plot antara nilai prediksi variabel dependen yaitu ZPRED dengan residualnya SRESID.

\section{Gambar 3}

\section{Uji Heteroskedastisitas}

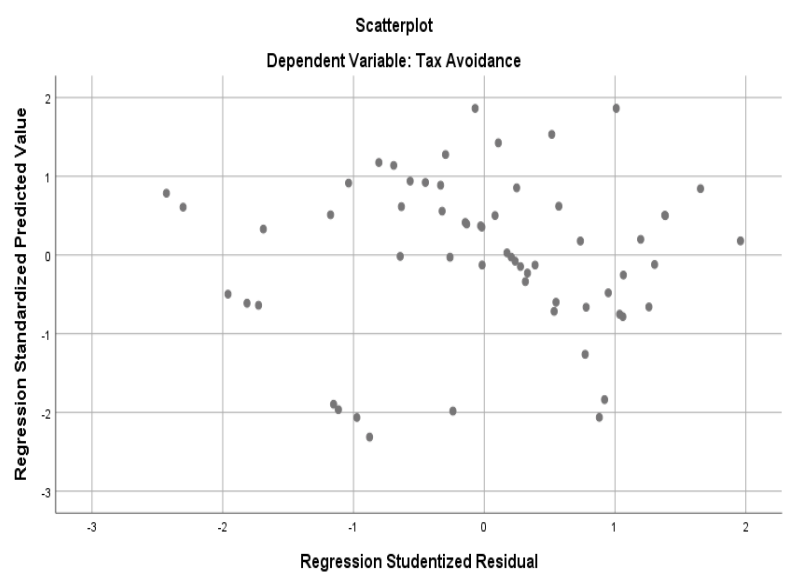

Sumber: Output SPSS 25 Tahun 2020

Berdasarkan gambar 3 diatas, dapat dilihat dibawah saja. Sehingga bisa disimpulkan bahwa bahwa titik-titik menyebar secara acak. Titik-titik tidak ditemukan heteroskedastisitas dalam penelitian data juga tidak mengumpul hanya diatas atau ini.

\section{Hasil Uji Autokorelasi}

\begin{tabular}{|c|c|c|c|c|c|c|}
\hline $\mathrm{c}$ & & $\begin{array}{l}\text { Unstar } \\
\text { ze } \\
\text { Coeffi }\end{array}$ & $\begin{array}{l}\text { dardi } \\
\text { d } \\
\text { cients } \\
\text { Std. } \\
\text { Erro } \\
\text { r }\end{array}$ & $\begin{array}{c}\text { Standa } \\
\text { rdized } \\
\text { Coeffic } \\
\text { ients }\end{array}$ & $\mathrm{t}$ & Sig. \\
\hline \multirow[t]{5}{*}{1} & $\begin{array}{l}\text { (Consta } \\
\text { nt) }\end{array}$ & .207 & .033 & & 6.318 & .000 \\
\hline & $\mathrm{TC}$ & .085 & .051 & .398 & 1.659 & .103 \\
\hline & CI & .182 & .086 & .255 & 2.108 & .040 \\
\hline & KRF & -.093 & .033 & -.331 & -2.806 & .007 \\
\hline & TC KI & -.113 & .066 & -.410 & -1.718 & .091 \\
\hline
\end{tabular}

Uji autokorelasi dalam penelitian ini yaitu dengan melihat nilai DW $<-2$ berarti terjadi dilakukan dengan melihat nilai Durbin Watson. Cara autokorelasi positif, nilai DW diantara -2 atau +2 untuk mengetahui ada atau tidaknya autokorelasi berarti tidak terjadi autokorelasi 
Tabel 5

Uji Autokorelasi

Model Summary

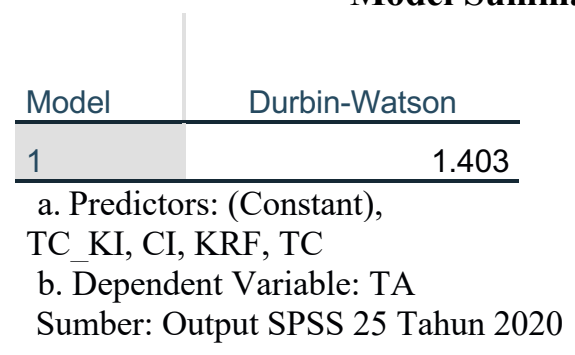

Tabel 5 diatas menunjukkan bahwa nilai model regresi tidak terdapat autokorelasi Durbin Watson yaitu 1,403 , dimana nilai berada diantara -2 atau +2 . Maka dapat disimpulkan bahwa Hasil Uji F (Uji Kelayakan Model)

\section{Tabel 6 \\ Hasil Uji F \\ Anova $^{a}$}

\begin{tabular}{|c|c|c|c|c|c|c|}
\hline \multicolumn{2}{|c|}{ Model } & $\begin{array}{c}\text { Sum of } \\
\text { Square } \\
\text { S }\end{array}$ & $\mathrm{df}$ & $\begin{array}{c}\text { Mean } \\
\text { Squa } \\
\text { re }\end{array}$ & F & Sig. \\
\hline \multirow[t]{3}{*}{1} & $\begin{array}{l}\text { Regr } \\
\text { essio } \\
n\end{array}$ & .234 & 4 & .059 & $\begin{array}{r}4.90 \\
2\end{array}$ & $.002^{\mathrm{b}}$ \\
\hline & $\begin{array}{l}\text { Resid } \\
\text { ual }\end{array}$ & .657 & 55 & .012 & & \\
\hline & Total & .891 & 59 & & & \\
\hline
\end{tabular}

a. Dependent Variable: TA

b. Predictors: (Constant), TC_KI, CI, KRF, TC

Sumber: Output SPSS 25 Tahun 2020

Berdasarkan Tabel 6 diatas, diperoleh nilai dapat disimpulkan bahwa model dalam penelitian ini signifikansi sebesar 0,002 Terlihat bahwa nilai layak untuk digunakan.

signifikansi tersebut lebih kecil dari 0,05. Maka

\section{Hasil Uji t (Uji Parsial)}




\section{Tabel 7 \\ Hasil Uji t (Uji Parsial) \\ Coefficients $^{\mathrm{a}}$}

\begin{tabular}{|c|c|c|c|c|c|c|}
\hline & & \multicolumn{2}{|c|}{$\begin{array}{l}\text { Unstandardi } \\
\text { zed } \\
\text { Coefficients }\end{array}$} & \multirow[t]{2}{*}{$\begin{array}{c}\text { Standa } \\
\text { rdized } \\
\text { Coeffic } \\
\text { ients }\end{array}$} & \multirow[b]{2}{*}{$t$} & \multirow[b]{2}{*}{ Sig. } \\
\hline $\mathrm{c}$ & & B & $\begin{array}{l}\text { Std. } \\
\text { Erro } \\
r\end{array}$ & & & \\
\hline \multirow[t]{5}{*}{1} & $\begin{array}{l}\text { (Consta } \\
\text { nt) }\end{array}$ & .207 & .033 & & 6.318 & .000 \\
\hline & TC & .085 & .051 & .398 & 1.659 & .103 \\
\hline & CI & .182 & .086 & .255 & 2.108 & .040 \\
\hline & KRF & -.093 & .033 & -.331 & -2.806 & .007 \\
\hline & TC KI & -.113 & .066 & -.410 & -1.718 & .091 \\
\hline
\end{tabular}

a. Dependent Variable: Tax Avoidance

Sumber: Output SPSS 25 Tahun 2020

Berdasarkan Hasil Uji Analisis Regresi Moderasi yang digambarkan melalui Uji t diatas, maka didapatkan Model Penelitian ini sebagai berikut:

$\mathrm{TA}=0,207+0,085 \mathrm{TC}+0,182 \mathrm{CI}-0,093 \mathrm{KRF}-$ 0,113TC_KI + e

Keterangan:

$\mathrm{TC}=$ Thin Capitalization

CI $=$ Capital Intensity

KRF = Kompensasi Rugi Fiskal

TC_KI =Thin Capitalization

Kepemilikan Institusional

TA $=$ Tax Avoidance

$\mathrm{e} \quad=$ Standar error

Nilai Konstan sebesar 0,207 berarti Jika diasumsikan nilai dari variabel indepenpen yaitu Thin Capitalization, Capital Intensity, Kompensasi Rugi Fiskal, dan Thin Capitalization yang dimoderasi oleh Kepemilikan Institusional adalah sama dengan nol, maka nilai variabel dependen yaitu Tax Avoidance adalah 0,207.

\section{Pembahasan}

Pengaruh Thin Capitalization terhadap Tax Avoidance
Berdasarkan hasil analisis statistik pada tabel 7, diketahui bahwa Thin Capitalization memiliki nilai koefisien regresi sebesar 0,085 yang artinya jika terjadi peningkatan Thin Capitalization sebesar 1 satuan maka Tax Avoidance akan meningkat sebesar 0,085 dengan catatan variabel tetap (konstan) dan nilai signifikansi Thin Capitalization sebesar 0,103 lebih besar dari 0,05. Maka dapat disimpulkan bahwa H1 ditolak yang berarti bahwa Thin capitalization tidak berpengaruh terhadap Tax Avoidance. Hasil penelitian ini sejalan dengan hasil penelitian (Ismi \& Linda, 2016) dan (Dharmawan et al., 2017).

Dalam penelitian ini Thin Capitalization tidak berpengaruh terhadap Tax Avoidance disebabkan karena nilai DER pada objek yang diteliti relatif kecil. Berdasarkan statistik deskriptif, nilai rata-rata DER pada perusahaan yang diteliti hanya sebesar 0,8487 . Mayoritas nilai DER berada pada rentang 0 sampai dengan 2 . Dari 60 perusahaan sektor pertambangan yang menjadi objek penelitian tidak ada perusahaan sektor pertambangan yang memiliki nilai DER > 4. Ditinjau dari sisi ketentuan perpajakan, (Peraturan Menteri Keuangan Nomor. 169/PMK.010/2015, 2015) mengatur bahwa besarnya perbandingan antara utang dan modal ditetapkan paling tinggi sebesar empat dibanding satu $(4: 1)$. Berdasarkan ketentuan tersebut dapat diketahui bahwa nilai 
DER maksimum yang diperbolehkan adala Ketentuan tersebut menyiratkan bahwa Otoritas Pajak menentukan bahwa nilai DER yang tidak lebih dari 4 bahkan masih jauh dari 4 masih dalam batasan wajar karena tidak akan berpengaruh terhadap kewajiban perpajakan perusahaan. Dengan demikian ketentuan tersebut telah sesuai dengan hasil penelitian ini.

\section{Pengaruh Capital Intensity terhadap Tax Avoidance}

Berdasarkan hasil analisis statistik pada tabel 7, diketahui bahwa Capital Intensity memiliki nilai koefisien regresi sebesar 0,182 yang artinya jika terjadi peningkatan Capital Intensity sebesar 1 satuan maka Tax Avoidance akan meningkat sebesar 0,182 dengan catatan variabel tetap (konstan) dan nilai signifikansi Capital Intensity sebesar 0,040 lebih kecil dari 0,05. Maka dapat disimpulkan bahwa $\mathrm{H} 2$ diterima yang berarti bahwa Capital Intensity berpengaruh positif terhadap Tax Avoidance. Hasil penelitian ini sejalan dengan hasil penelitian (Anggraini et al., 2020), (Muzakki \& Darsono, 2015), dan (Suprianto \& Aqida, 2020).

Capital Intensity atau Intensitas modal mencerminkan besaran modal yang dibutuhkan perusahaan untuk memperoleh laba, dimana sumber dana salah satunya diperoleh dari penurunan aktiva tetap ataupun kenaikan jumlah aktiva tetap Biaya depresiasi aset tetap ini menjadi penambah beban perusahaan dan memperkecil laba. hal ini terjadi karena penyusutan aset tetap perusahaan dari tahun ke tahun yang secara langsung dapat menurunkan laba yang menjadi dasar perhitungan pajak. Maka dapat disimpulkan bahwa banyak perusahaan sektor pertambangan yang meningkatkan jumlah aktiva tetapnya, Sehingga Capital Intensity akan semakin tinggi dan penghindaran pajak yang dilakukan juga akan semakin tinggi.

\section{Pengaruh Kompensasi Rugi Fiskal terhadap Tax Avoidance}

Berdasarkan hasil analisis statistik pada tabel 7, diketahui bahwa Kompensasi Rugi Fiskal memiliki nilai koefisien regresi sebesar -0,093 yang artinya jika terjadi penurunan Kompensasi Rugi Fiskal sebesar 1 satuan maka Tax Avoidance akan berkurang sebesar 0,093 dengan catatan variabel tetap (konstan) dan nilai signifikansi Kompensasi Rugi Fiskal sebesar 0,007 lebih kecil dari 0,05. Maka dapat disimpulkan bahwa $\mathrm{H} 3$ diterima yang berarti
4. bahwa Kompensasi Rugi Fiskal berpengaruh negative terhadap Tax Avoidance. Hasil penelitian ini sejalan dengan hasil penelitian (Kurniasih \& Ratna Sari, 2013), (Mulyani et al., 2012), dan (Situmorang, 2018).

Dalam hasil penelitian ini diketahui bahwa Kompensasi Rugi Fiskal berpengaruh ngeatif terhadap Tax Avoidance. Maka dapat disimpulkan bahwa hanya sedikit perusahaan sektor pertambangan yang memiliki kompensasi rugi fiskal, yang menyebabkan laba perusahaan tidak berkurang karena tidak adanya laba perusahan yang digunakan untuk mengurangi atau menutupi jumlah kompensasi rugi fiskal tersebut. Hal ini akan mendorong perusahaan untuk melakukan praktik penghindaran pajak atau Tax Avoidance. Hasil penelitian ini sesuai dengan (Undang-Undang No. 36 Tahun 2008 Tentang Pajak Penghasilan, 2008) Pasal 6 ayat 2 yang menyebutkan bahwa perusahaan yang telah merugi dalam satu periode akuntansi diberikan keringanan untuk membayar pajaknya. Kerugian tersebut dapat dikompensasikan selama lima tahun ke depan. dan laba perusahaan akan digunakan untuk mengurangi jumlah kompensasi kerugian tersebut.

\section{Kepemilikan Institusional dalam memoderasi pengaruh Thin Capitalization terhadap Tax Avoidance}

Berdasarkan hasil analisis statistik diketahui bahwa Thin Capitalization yang telah dimoderasi dengan Kepemilikan Institusional memiliki nilai koefisien regresi sebesar $-0,113$ yang artinya jika terjadi penurunan Thin Capitalization yang dimoderasi oleh Kepemilikan Institusional sebesar 1 satuan maka Tax Avoidance akan berkurang sebesar 0,113 dengan catatan variabel tetap (konstan) dan nilai signifikansi sebesar 0,091 lebih besar dari 0,05. Maka dapat disimpulkan bahwa H4 ditolak yang berarti bahwa Kepemilikan Institusional tidak dpat memoderasi pengaruh Thin capitalization terhadap Tax Avoidance. Hasil penelitian ini sejalan dengan hasil penelitian (Olivia \& Dwimulyani, 2019).

Hal ini berarti bahwa dengan adanya kepemilikan institusional dalam suatu perusahaan, tidak terbukti dapat memberikan peran manajemen dalam mengambil kebijakan pendanan hutang karena hal tersebut dapat berdampak pada penilaian stakeholders dalam membaca laporan keuanga suatu perusahaan. 


\title{
Hasil Uji Koefisien Determinasi (Adjusted R Square)
}

Tabel 8

\section{Hasil Uji Koefisien Determinasi}

\author{
Model Summary \\ \begin{tabular}{lc|c|c|}
\multicolumn{2}{l|}{ Mode } & & \\
$\mathrm{I}$ & $\mathrm{R}$ & $\mathrm{R}$ Square & Adjusted R Square \\
\hline 1 & $.513^{\mathrm{a}}$ & .263 & .209 \\
\hline a. & Predictors: (Constant), Moderasi, Capital Intensity,
\end{tabular} \\ Kompensasi Rugi Fiskal, Thin Capitalization \\ b. Dependent Variable: Tax Avoidance \\ Sumber: Output SPSS 25 Tahun 2020
}

Pada tabel 8 diatas, terlihat nilai Adjusted $\mathrm{R}$ square sebesar 0,209 atau 20,9\%. Hal ini menunjukkan bahwa Thin Capitalization, Capital Intensity, Kompensasi Rugi Fiskal, dan Kepemilikan Institusional sebagai variabel moderasi dapat

\section{KESIMPULAN DAN SARAN}

Dari hasil penelitian yang telah dilakukan dapat disimpulkan bahwa Thin Capitalization tidak berpengaruh terhadap Tax Avoidance, Capital Intensity berpengaruh positif terhadap Tax Avoidance, Kompensasi Rugi Fiskal berpengaruh negatif terhadap Tax Avoidance, dan Kepemilikan

\section{DAFTAR PUSTAKA}

2008. Undang-Undang No. 36 Tahun 2008 Tentang Pajak Penghasilan.

Agoes, S. dan E. (2013). Akuntansi Perpajakan (3rd ed.). Salemba Empat, Jakarta.

Anggraini, F., Astri, N. D., \& Minovia, A. F. (2020). Pengaruh Strategi Bisnis, Capital Intensity dan Ultinationality terhadap Tax Avoidance. MENARA Ilmu, XIV(02), 36-45.

Brigham, Eugene F dan Houston. 2006. Fundamental of FinancialManagement: Dasar-Dasar Manajemen Keuangan. Edisi 10. Jakarta: Salemba Empat.

Budiadnyani, N. P. (2020). Pengaruh Kompensasi Manajemen Pada Penghindaran Pajak Dengan Kepemilikan Instutisional Sebagai Variabel Pemoderasi. Jurnal Ilmiah Akuntansi Dan Bisnis, 5(1), 67-90.

Charisma, R. B., \& Dwimulyani, S. (2019). Pengaruh Struktur Kepemilikan Terhadap Tindakan Penghindaran Pajak Dengan Kualitas Audit Sebagai Variabel Moderating. Prosiding Seminar Nasional Pakar, 2, 1-10.

Darmawan, I., \& Sukartha, I. (2014). Pengaruh Penerapan Corporate Governance, Leverage, Roa, Dan Ukuran Perusahaan Pada Penghindaran Pajak. E-Jurnal Akuntansi, 9(1), 143-161.

Dewi. N N K \& mempengaruhi Tax Avoidance sebesar 20,9\% sedangkan sisanya $79,1 \%$ dijelaskan oleh variabel lain diluar model.

Institusional tidak dapat memoderasi pengaruh Thin Capitalization terhadap Tax Avoidance. Hasil penelitian ini tidak dapat di generalisir, karena penelitian ini hanya dilakukan pada perusahaan sektor pertambangan yang terdaftar di Bursa Efek Indonesia periode 2017-2019.

eksekutif, karakteristik perusahaan, dan dimensi tata kelola perusahaan yang baik pada tax avoidance di bursa efek indonesia. 2, 249-260.

Dharmawan, P. E., Djaddang, S., \& Dharmansyah. (2017). Determinan Penghindaran Pajak Dengan Corporate Social Responsibility Sebagai Variabel Moderasi. Jurnal Riset Akuntansi Dan Perpajakan JRAP, Vol.4(No.2), PP.183195.

Fadila, M. (2017). Pengaruh Return On Assets, Leverage, Ukuran Perusahaan, Kompensasi Rugi Fiskal, Kepemilikan Institusional, Dan Koneksi Politik Terhadap Penghindaran Pajak. JOM Fekon, 4(1), 1671-1684.

Ghozali, I. (2018). Aplikasi Analisis Multivariate dengan Program IBM SPSS 25 (9th ed.). Badan Penerbit Universitas Diponegoro.

Ginting, S. (2016). Pengaruh Corporate Governance dan Kompensasi Rugi Fiskal Terhadap Penghindaran Pajak dengan Ukuran Perusahaan Sebagai Variabel Moderating. Jurnal Wira Ekonomi Mikroskil, 6(2), 165-176.

Houston, B. F., \& Eugene. (2006). Fundamental of FinancialManagement: Dasar-Dasar Manajemen Keuangan (10th ed.). Salemba Empat.

Ismi. F. \& Linda. (2016). Pengaruh Thin Capitalization . Return 
On Asset, Dan Corporate Governance Pada Perusahaan Jakarta Islami Index ( JII ). Jurnal Ilmiah Mahasiswa Ekonomi Akuntansi, 1(1), 150-165.

Jensen, C., \& Meckling, H. (1976). THEORY OF THE FIRM: MANAGERIAL BEHAVIOR , AGENCY COSTS AND OWNERSHIP STRUCTURE I. Introduction and summary In this paper $W C$ draw on recent progress in the theory of (1) property rights, firm. In addition to tying together elements of the theory of e. 3, 305-360.

Jumailah, V., \& Mulyani, S. D. (2020). Pengaruh Thin Capitalization Dan Konservatisme Akuntansi Terhadap Tax Avoidance Dengan Kepemilikan Institusional Sebagai Variabel Moderasi. Journal of Chemical Information and Modeling, 53(9), 1689-1699.

Kalbuana, N., Purwanti, T., \& Agustin, N. H. (2017). Pengaruh Kepemilikan Manajerial, Beban Pajak Tangguhan, dan Tingkat Pajak Efektif Terhadap Penghindaran Pajak di Indonesia. Magistra, 100, 26-35.

Khomsatun, S., \& Martani, D. (2015). Pengaruh Thin Capitalization dan Assets Mix Perusahaan Indeks Saham Syariah Indonesia (Issi) Terhadap Penghindaran Pajak. Simposium Nasional Akuntansi XVIII, 1-23.

Kurniasih, T., \& Ratna Sari, M. (2013). Pengaruh Return on Assets, Leverage, Corporate Governance, Ukuran Perusahaan Dan Kompensasi Rugi Fiskal Pada Tax Avoidance. Buletin Studi Ekonomi, 18(1), 58-66.

Mulyana, Y., Mulyati, S., \& Umiyati, I. (2020). Pengaruh Komisaris Independen, Kompensasi Rugi Fiskal Dan Pertumbuhan Aset Terhadap Penghindaran Pajak. Jurnal SIKAP (Sistem Informasi, Keuangan, Auditing Dan Perpajakan), 4(2), https://doi.org/10.32897/jsikap.v4i2.202

Mulyani, S., Darminto, \& N.P, M. . W. E. (2012). PENGARUH KARAKTERISTIK PERUSAHAAN, KONEKSI POLITIK DAN REFORMASI PERPAJAKAN TERHADAP PENGHINDARAN PAJAK (STUDI PADA PERUSAHAAN MANUFAKTUR YANG TERDAFTAR DI BURSA EFEK TAHUN 2008-2012).

Muzakki, M. R., \& Darsono. (2015). Pengaruh Corporate Social Responsibility Dan Capital Intensity Terhadap Penghindaran Pajak. E-Jurnal Akuntansi, 4(3), 445-452.

Olivia, I., \& Dwimulyani, S. (2019). Pengaruh Thin Capitalization dan Profitabilitas Terhadap Penghindaran Pajak dengan Kepemilikan Institusional sebagai Variabel Moderasi. Prosiding Seminar Nasional Pakar Ke 2: Sosial Dan Humaniora, 1-10.

Pajriyansyah, R.-, \& Firmansyah, A.-. (2017). Pengaruh
Leverage, Kompensasi Rugi Fiskal Dan Manajemen Laba Terhadap Penghindaran Pajak. Keberlanjutan, 2(1), 431. https://doi.org/10.32493/keberlanjutan.v2i1.y2017.p431459

Peraturan Menteri Keuangan Nomor. 169/PMK.010/2015, (2015).

Putri, V. R. (2020). Penghindaran Pajak Pada Bank Umum: Dipengaruhi Oleh Karakter Eksekutif, Kualitas Audit, Komite Audit, Kompensasi Rugi Fiskal ... Jurnal Manajemen Dayasaing.

Situmorang, N. S. B. (2018). PENGARUH LEVERAGE, KOMPENSASI RUGI FISKAL, UKURAN PERUSAHAAN, DAN KEPEMILIKAN KELUARGA TERHADAP TAX AVOIDANCE. JOM FEB, 1 .

Sueb, M. (2020). Penghindaran Pajak: Thin Capitalization Dan Asset Mix. JIAFE (Jurnal Ilmiah Akuntansi Fakultas Ekonomi), 6(1), Press. https://doi.org/10.34204/jiafe.v6i1.2052

Suprianto, E., \& Aqida, U. (2020). Karakteristik Eksekutif, Intensitas Modal \& Tax Avoidance. Jurnal Akuntansi Indonesia, 9(1), 11-18.

Taylor, G., \& Richardson, G. (2013). The determinants of thinly capitalized tax avoidance structures: Evidence from Australian firms. Journal of International Accounting, Auditing and Taxation, 22(1), 12-25. https://doi.org/10.1016/j.intaccaudtax.2013.02.005

Undang-Undang No. 36 Tahun 2008 Tentang Pajak Penghasilan, (2008).

Undang-Undang Nomor 28 Tahun 2007 Tentang Perubahan Ketiga atas Undang-Undang Nomor 6 Tahun 1983 Tentang Ketentuan Umum dan Tata Cara Perpajakan, (2007).

Waluyo, T. M., Basri, Y. M., \& Rusli, R. (2015). Pengaruh Return on Asset, Leverage, Ukuran Perusahaan, Kompensasi Rugi Fiskal dan Kepemilikan Institusi Terhadap Penghindaran Pajak. 1-25.

Widodo, L. L., Diana, N., \& Mawardi, M. C. (2020). Pengaruh Multinasionalitas, Good Coorporate Governance, Tax Haven, Dan Thin Capitalization Terhadap Praktik Penghindaran Pajak Pada Perusahaan Multinasional Yang Terdaftar Di Bei Periode Tahun 2016-2018. E-Jra, 09(06), 119-133.

Zemzem, A., \& Ftouhi, K. (2013). The Effects of Board of Directors ' Characteristics on Tax Aggressiveness. Research Journal in Finance and Accounting, 4(4), 140148. 